\title{
First representatives of the genus Fierscyclops Karanovic, 2004 (Copepoda, Cyclopidae) from South East Asia
}

\author{
Chaichat BOONYANUSITH, ${ }^{1}$ Anton BRANCELJ,${ }^{2}$ La-orsri SANOAMUANG ${ }^{1,3^{*}}$ \\ ${ }^{1}$ Applied Taxonomic Research Center, Faculty of Science, Khon Kaen University, Khon Kaen 40002, Thailand; ${ }^{2}$ National Institute of \\ Biology, Večna pot 111, SI-1000 Ljubljana, Slovenia; ${ }^{3}$ Faculty of Science, Mahasarakham University, Maha Sarakham 44150, Thailand \\ *Corresponding author: la_orsri@kku.ac.th
}

\begin{abstract}
We describe two new species of the genus Fierscyclops Karanovic, 2004, F. tanaosriensis $n$. sp. and F. solaris $n$. sp. from western Thailand, which are also the first records of this genus in Southeast (SE) Asia (and also Asia). The two new species share several characters such as: i) presence of lateral sensillum on the caudal ramus in both females and males; ii) one-segmented swimming leg 5 (P5) inserted on the lateral corner of the thoracic somite 5; iii) free segment of P5 with two elements (spine and seta), apical inner spine is robust, insertion distance between the apical spine and apical seta is relatively large; iv) swimming legs 1-4 (P1-P4) rami are two-segmented; v) distal segment of endopod (Endp2) of P4 has two apical spines; vi) spine and seta formula of distal segment of exopod (Exp2) of P1-P4 are 3.4.4.3 and 5.5.5.5, respectively; vii) coxobasis and Endp2 of the antenna have two and 10 setae, respectively. The two new species differ from the Australian type-species of the genus F. fiersi (De Laurentiis, Pesce \& Humphreys, 2001) in: i) setation of the antenna; ii) longer inner apical spine on P5; iii) relatively longer genital double-somite in female; iv) relatively shorter caudal rami; v) presence of lateral sensillum on the caudal ramus in both females and males. The Thai species differ from one another in: i) ornamentation of the body integument; ii) shape of the posterior margin of the thoracic somite 2; iii) spinule ornamentation of the syncoxa of the maxilliped; iv) shape of the medial expansion of P2-P4 basis in females.
\end{abstract}

Key words: Cyclopoida, groundwater, karst, Southeast Asia, Thailand.

Received: December 2012. Accepted: July 2013.

\section{INTRODUCTION}

Information on the diversity of freshwater cyclopoid copepods in Thailand and neighbouring Southeast (SE) Asian countries primarily originates from the sampling of various surface aquatic habitats such as rivers, lakes, manmade reservoirs, rice fields, temporary pools, and irrigation channels (Bricker et al., 1978; Boonsom, 1984; Lim and Fernando, 1985; Sanoamuang, 1999; Alekseev and Sanoamuang, 2006; Chaichareon et al., 2011). As a result of the intensive sampling of zooplankton in central and northeastern regions of Thailand, 45 species of freshwater cyclopoids have been recorded there (Alekseev and Sanoamuang, 2006). Nonetheless, a large portion of the cyclopoid fauna is likely unknown due to the lack of information available on the diversity of copepods from other regions and the missing knowledge on benthic and subterranean environments. This results in an underestimation of the cyclopoid species richness of SE Asia.

Compared to surface environments, subterranean habitats in karst host a higher proportion of geographically isolated taxa (endemics) that are often recognised as mono- or oligospecific genera (Gibert and Deharveng, 2002). They are frequent in unsaturated zones of karst, especially in epikarst in temperate zones (Brancelj, 2000, 2005, 2009).
In Thailand, for a long time, only one cyclopoid, Tropocyclops prasinus (Fischer, 1860) had been reported from caves (Deharveng and Bedos, 2000). However, the subterranean occurrence of this copepod is probably accidental as the species is common in surface water-bodies (Dussart and Defaye, 2006). More recently, the number of copepods collected from caves and other subterranean habitats in Thailand has increased due to more intensive activity in sampling. A sampling expedition in the northeastern karst of central Thailand in 2003, provided a new cyclopoid species, Afrocyclops henrii Alekseev \& Sanoamuang, 2006, from a mountainous stream in Petchabun province (Alekseev and Sanoamuang, 2006). Stygobiotic Bryocyclops maewaensis Watiroyram, Brancelj \& Sanoamuang, 2012, as the first representative of this genus in Thailand, was collected from three caves in the northern and western regions in 2010 (Watiroyram et al., 2012). Sampling of cavedwelling copepods in the karst regions of western Thailand in 2011 resulted in the discovery of a new species of a Metacyclops, related to M. cushae Reid, 1991 (southern North and tropical South America) (Reid, 1991) and accompanied by some additional, not yet described species. They were collected during a sampling campaign on cavedwelling copepods in 15 caves in a karstic area of Kanchanaburi and Ratchaburi provinces, western Thailand. The 
area belongs to the Kwai Noi river sub-basin, which is part of the Mae Klong river basin. Fifteen sampling localities (i.e. caves and adjacent springs) were sampled there. The new species described herein come from two localities: i) stream in Keao Sawan Badan cave and ii) small spring located in the entrance area of a nameless cave. Both sampling localities are located in the area of the Tanaosri mountains in Sangkhlaburi district, Kanchanaburi province. They are in isolated cone karst (represented as small hills, up to $50 \mathrm{~m}$ high), about $40 \mathrm{~km}$ apart. At present, there is no known surface or subsurface hydrological connection between these localities.

In this paper we described two new species of Fierscyclops Karanovic, 2004, which were collected from the two above mentioned localities in western Thailand. The genus was established to accommodate Metacyclops fiersi De Laurentiis, Pesce \& Humphreys, 2001, from Eneabba, western Australia (Karanovic, 2004a). The species was originally collected from a bore hole in a karstic area (De Laurentiis et al., 2001); and so far, no other species of this genus have been recorded outside Australia. Our finding is the first record of the genus in SE Asia and enlarges the distribution of the genus to another biogeographical region. Some additional characters of the genus Fierscyclops were observed in the specimens from Thailand and are discussed.

\section{METHODS}

Samples were collected with a hand net ( $60 \mu \mathrm{m}$ mesh size), placed in plastic bottles and fixed in formaldehyde solution with a final concentration of about $4 \%$. Animals were sorted under a stereomicroscope and stored in $70 \%$ ethanol. For taxonomic identification, specimens were transferred into a mixture of glycerol and $70 \%$ ethanol (ratio $\sim 1: 10 \mathrm{v} / \mathrm{v}$ ), which was replaced within $30 \mathrm{~min}$ by pure glycerol. Afterwards, whole specimens were examined under an Olympus compound microscope $(\mathrm{CH} 30$; Olympus, Tokyo, Japan) at a magnification of $\times 400$. They were dissected at the magnification of $\times 80$. Appendages and surface ornamentation of the body were examined under a magnification of $\times 1000$. Some details were later observed by a scanning electron microscope (SEM) (Leo 1450VP). All drawings, except female and male habitus, were made at the same magnification $(\times 1000)$. The final versions of illustrations were prepared using the CorelDraw ${ }^{\circledR} 12$ graphic programme (Corel Draw, Mountain View, CA, USA).

Nomenclature and descriptive terminology follows Huys and Boxshall (1991).

\section{RESULTS}

Order Cyclopoida Burmeister, 1834

Family Cyclopidae Dana, 1846

Genus Fierscyclops Karanovic, 2004
Fierscyclops tanaosriensis n. sp.

\section{Taxonomical account}

Type locality: Kaeo Sawan Badan cave (Sangkhlaburi district) is located in an isolated small cone karst area, about $230 \mathrm{~km}$ northwest of Kanchanaburi town and about $300 \mathrm{~km}$ northwest of Bangkok. The cave is about $120 \mathrm{~m}$ long, with two openings. The wider opening (=entrance) is located about $20 \mathrm{~m}$ above a valley floor. The coordinates of the entrance are: $15^{\circ} 18^{\prime} 17.2^{\prime \prime} \mathrm{N} ; 98^{\circ} 24^{\prime} 48.8^{\prime \prime} \mathrm{E}$, elevation $330 \mathrm{~m}$ asl. The horizontal gallery is divided into three levels. In the middle level there is a small stream originating from the forest outside the cave. Water enters the cave through cracks in a distal part of the gallery. After $50 \mathrm{~m}$, the stream drops for $5 \mathrm{~m}$ to the lower level, forming a small pool in a semi-illuminated zone, where the new species was collected by one of the authors (CB) on 15 June 2010. The whole gallery (three levels combined) is $15-20 \mathrm{~m}$ high and 15-20 m wide. Water flow was slow, water temperature was $24.8^{\circ} \mathrm{C}, \mathrm{pH} 7.2$, and conductivity $464 \mu \mathrm{S} \mathrm{cm} \mathrm{cm}^{-1}$.

Material: Holotype: adult female; completely dissected and mounted on a slide in glycerol and sealed with nail polish; deposited in the Natural History Museum (London), registration No. NHM 2012.1494. Allotype: adult male, completely dissected and mounted on a slide in glycerol and sealed with nail polish; collected in the same place and time as the holotype: deposited in the Natural History Museum (London), registration No. NHM 2012.1500.

Paratypes (all specimens collected at the same time and locality as the holotype): 3 adults $\phi+9$ and 2 adults $\mathrm{o}^{\lambda}$; deposited in the Natural History Museum (London); registration Nos. NHM 2012.1495-1499. Six adults 우우 and 2 adults $\hat{\partial}$, deposited in the Science Museum of Khon Kaen University, Thailand; registration Nos. KKUCOP-2012-001. The remaining material collected at the same time and locality as holotype ( 8 adults $ㅇ+q$ and 1 adult $\delta^{\text {) }}$ deposited in the senior author's collection (AB).

Additional specimen: one adult $\hat{\sigma}$ processed for taking photographs by SEM.

Etymology: The specific name is derived from Tanaosri mountain where the cave is located.

\section{Description}

Female (holotype): total body length, measured from tip of rostrum to posterior margin of caudal rami, $828 \mu \mathrm{m}$. Prosome about 1.4 times as long as urosome (including caudal rami) (Fig. 1a). Preserved specimen transparent. Naupliar eye not discernible. Rostrum small, trapezoidal in frontal view, with 2 sensilla at $2 / 3$ length from tip (Fig. 1c). Body length/width ratio about 4 . Cephalothorax anteriorly oval, 1.1 times as long as wide, with greatest width at the posterior end of cephalothorax, representing $26 \%$ of body length. Posterior margins of all thoracic somites smooth. In- 
tegument smooth, not strongly chitinised, with no visible cuticular windows. Last three thoracic somites with 2 dorsal sensilla. Genital double-somite symmetrical; about 0.9 times as wide as long, tapering posteriorly (Fig. 1a and 1b), with 2 large lateral sensilla at 9/10 length of double-somite (Figs. $1 \mathrm{~b}$ and $2 \mathrm{e}$ ). Copulatory pore small, oval, situated at $1 / 4$ of somite length; copulatory duct short, narrow, sclerotised. Seminal receptacle about $1 / 4$ length of double-somite, with clear distinction between anterior and posterior expansions; anterior expansion very short, ribbon-shape; posterior one expanded laterally and slightly extended posteriorly (Fig. 1b). Paired gonopores situated laterally at $1 / 4$ of somite length, covered by a reduced P6 (Fig. 2e). Posterior margin of genital double-somite and two subsequent somites with smooth hyaline frill. Anal somite with ventro-lateral row of spinules on posterior margin, ornamented with 2 dorsal sensilla, and with short anal operculum; posterior border of anal operculum convex and smooth (Fig. 1a, 1d, 1e).

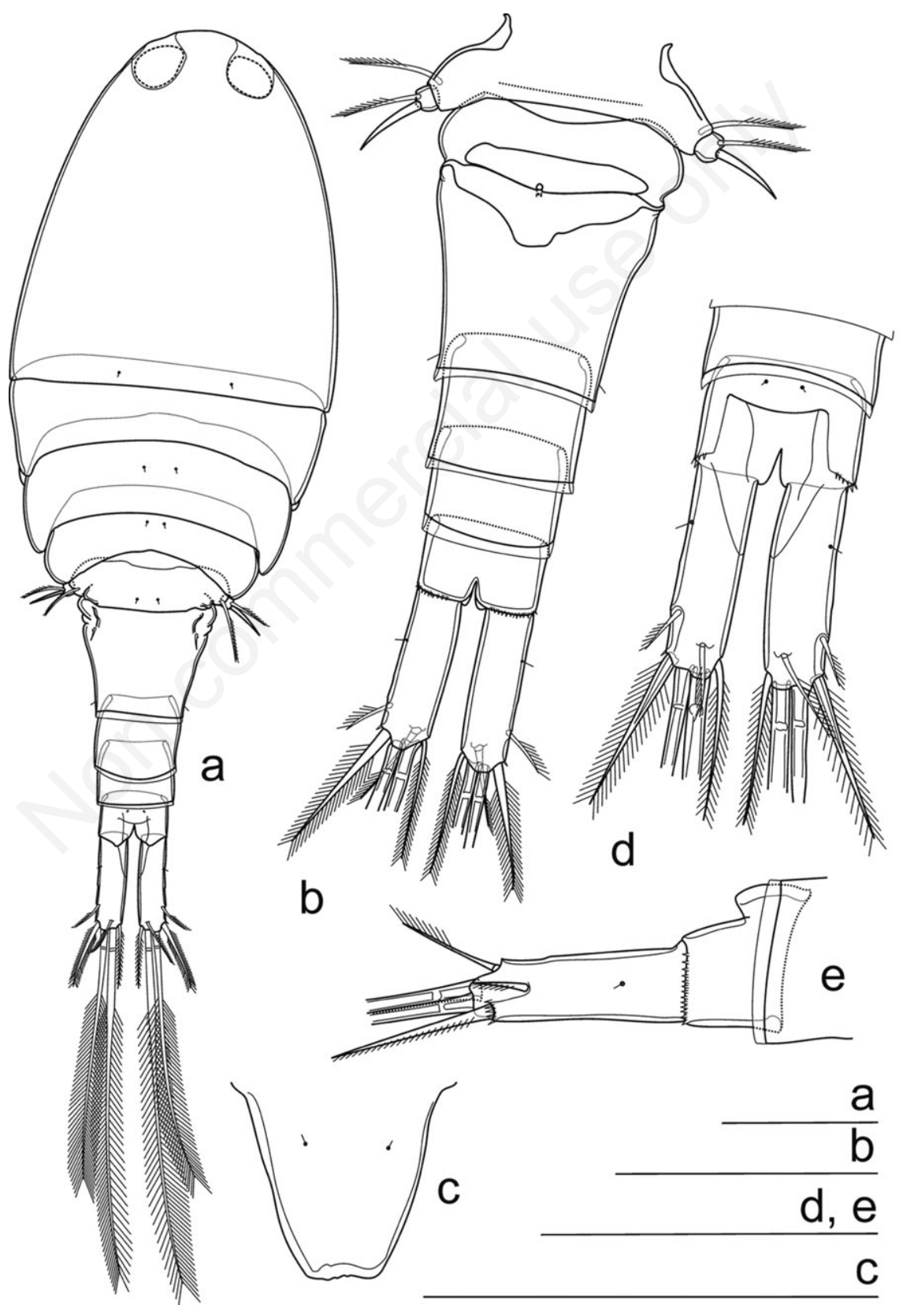

Fig. 1. Fierscyclops tanaosriensis n. sp., female (holotype): a) habitus, dorsal view; b) urosome, ventral view; c) rostrum, frontal view; d) anal somite and caudal rami, dorsal view; e) anal somite and caudal rami, lateral view. Scale bars: $0.1 \mathrm{~mm}$. 
Caudal rami (Figs. 1d, 1e and 3c): parallel; about 3 times as long as wide; outer margin with one lateral sensillum at about $1 / 4$ of ramus length, with a row of a few spinules at insertion of outermost apical seta (III) (Fig. 1b, $1 \mathrm{~d}, 1 \mathrm{e})$, with small lateral pore between lateral sensillum and lateral seta (II) (Fig. 3c). Lateral (II) and dorsal seta (VII) unipinnate, with short setules on outer margin in distal half of seta; remaining caudal setae bipinnate. Lateral seta (II) implanted distally at 3/4 length of caudal ramus.
Outermost apical seta (III) robust, slightly longer than innermost apical seta (VI). Outer median apical seta (IV) with breaking plane. Inner median apical seta (V), longest one, with breaking plane. Innermost apical seta (VI) slim and straight. Dorsal seta (VII) articulate at base, inserted near the posterior inner corner of ramus. Seta $V$ about 1.5 times as long as seta IV, and about 0.3 times as long as body length. Length ratio of caudal setae to ramus length, from seta II to seta VII: 0.4:0.8:2.9:4.0:0.8:0.7. Length

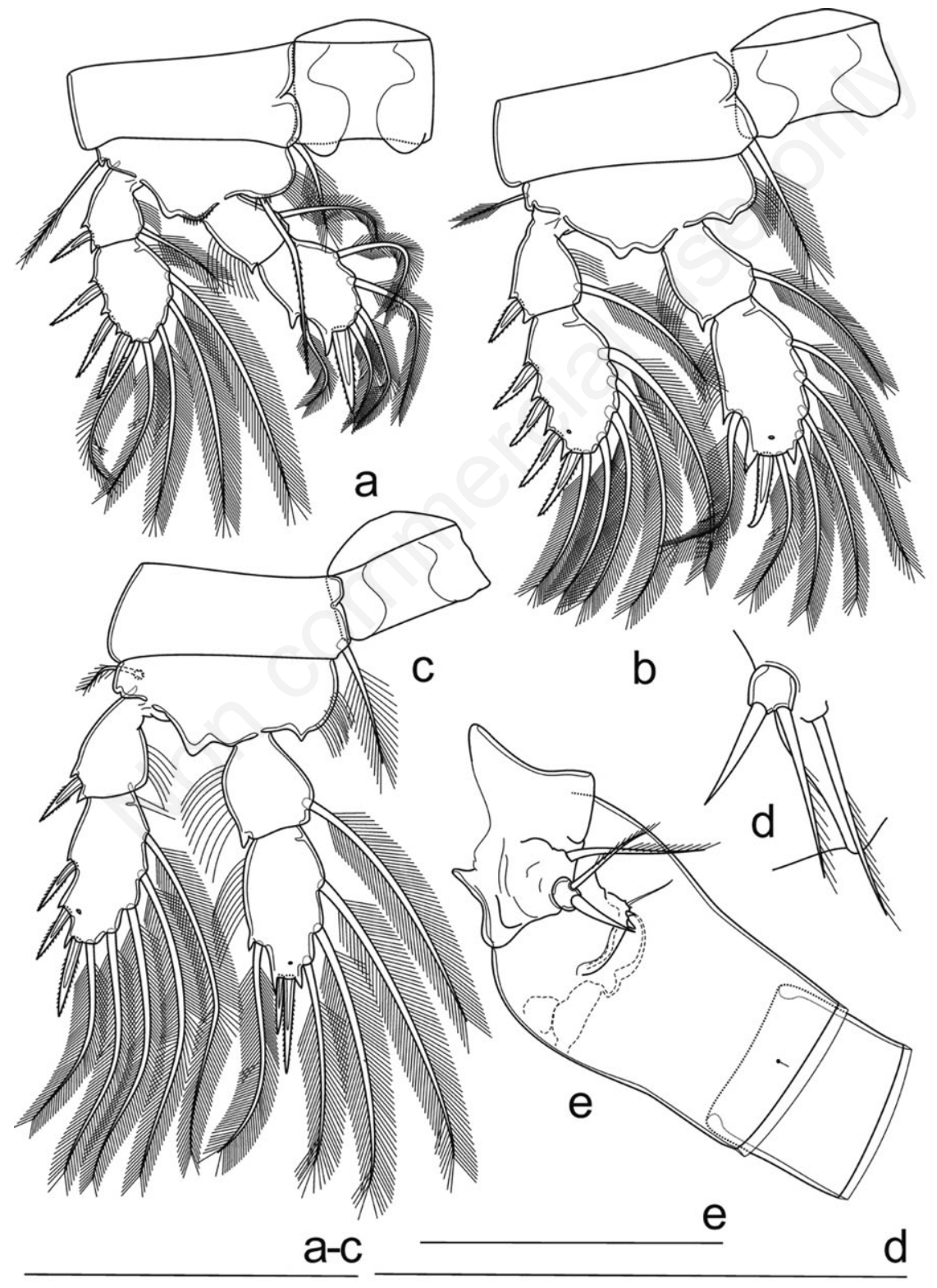

Fig. 2. Fierscyclops tanaosriensis n. sp., female (holotype): a) P1, frontal view; b) P2, frontal view; c) P4, frontal view; d) P5, lateral view; e) thoracic somite 5 and genital double-somite, lateral view. P1=swimming leg 1; P2=swimming leg 2; P4=swimming leg 4; $\mathrm{P} 5=$ swimming leg 5. Scale bars: $0.1 \mathrm{~mm}$. 

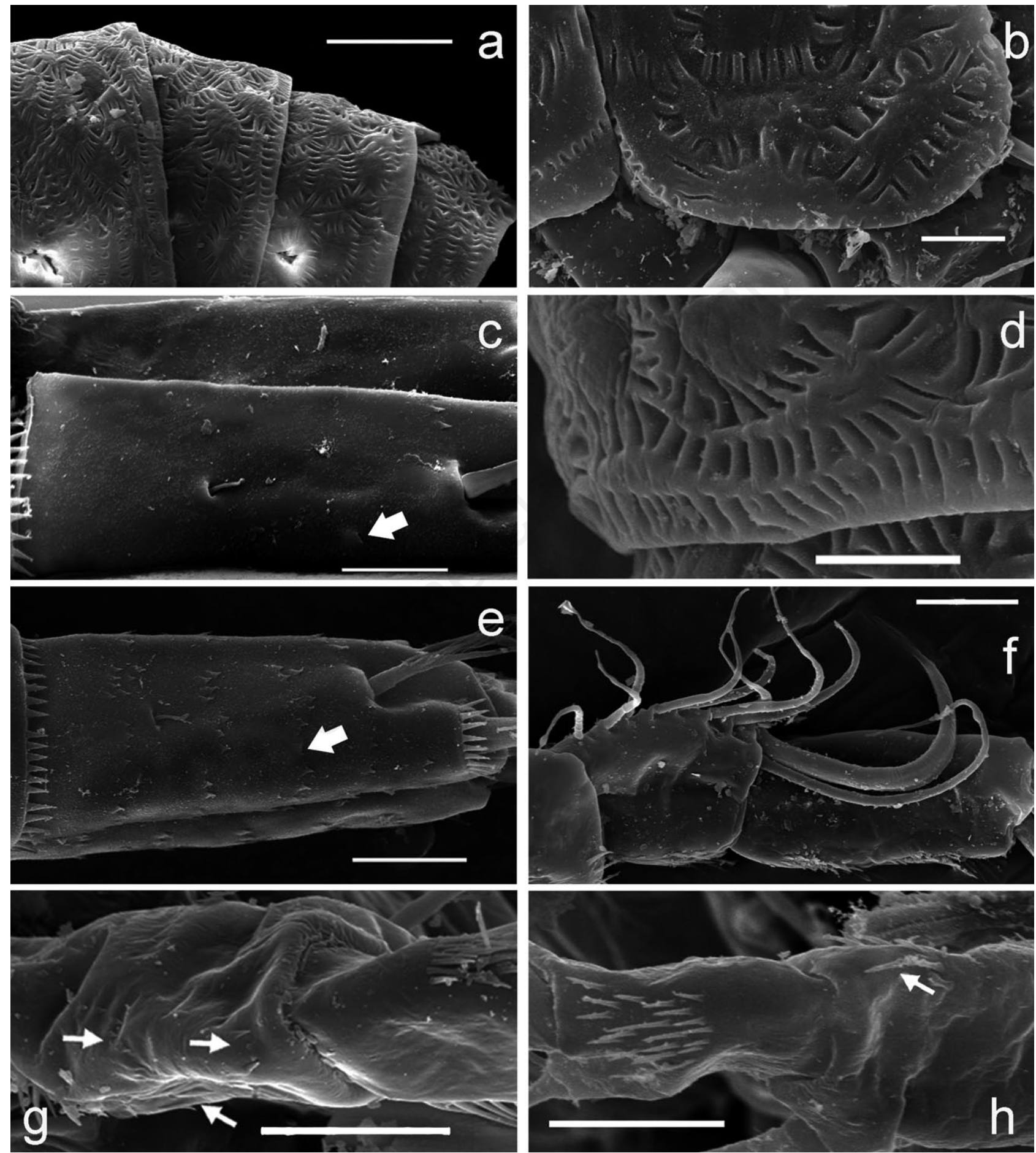

Fig. 3. Scanning electron micrographs. Fierscyclops solaris n. sp.: a,d-f) male; b,h) female. Fierscyclops tanaosriensis n. sp.: c,g) female. a) Part of prosome, dorsal view; b) posterior margin of thoracic somite 2, lateral view; c,e) left caudal rami, lateral view (arrows indicate small lateral pore); d) posterior margin of thoracic somite 2, dorsal view; f) second and third endopodal segments of antenna; $\mathrm{g}, \mathrm{h})$ outer margin of syncoxa of maxilliped (arrows indicate spinule row). Scale bars: $30 \mu \mathrm{m}(\mathrm{a}) ; 10 \mu \mathrm{m}(\mathrm{b}-\mathrm{h})$. 
ratio of caudal setae from seta II to seta VII: 1.0:2.3:7.8:10.9:2.1:1.8 (details in Tab. 1).

Antennule (Fig. 4a): 11-segmented, not reaching posterior margin of cephalothorax. Armature formula: 8.4.6.2.2.2.3.2+ae.2.2+ae.7+ae, where Arabic numbers the number of setae, and ae means aesthetasc. Fifth segment with short, spiniform seta on posterior outer corner. Aesthestasc on eighth and penultimate segment inserted near outer seta; aesthetasc on segment 8 as long as seta, on segment 10 about 0.5 times as long as seta. Terminal segment sub-apically with acrothek.

Antenna (Figs. 4b and 3f): 4-segmented, comprising coxobasis and 3-segmented endopod (Endp). Coxobasis robust, with a row of spinules on outer margin, armed with smooth seta on distal inner corner, with seta representing exopod (Exp) near distal margin on frontal surface. Seta representing Exp long, extending well beyond the tip of antenna. Proximal segment of endopod (Endp1) with a row of spinules along distal half of caudal margin; armed with smooth seta in the middle of inner margin. Middle segment of Endp as long as wide, with longitudinal row of minute spinules and with 10 smooth setae ( 8 lateral, 1 subapical and 1 apical; subapical seta robust and recurved). Endp3 about twice as long as wide, with 2 longitudinal rows of minute spinules and with 7 smooth apical setae.

Mandible (Fig. 4c): gnathobase with strongly chitinised teeth, with pinnate seta dorsally. Mandibular palp short, with short, slender seta and 2 long, plumose setae, ca. 8 times as long as short seta.

Maxillule (Fig. 4d): composed of robust praecoxa and 2 -segmented palp. Arthrite of praecoxa with 3 strong apical spines fused to praecoxa and distinct spiniform seta. Praecoxa with 6 armature elements along inner margin, proximalmost seta robust, and pinnate; 3 middle setae smooth, and thin; 2 distal setae robust, bearing few spinules. Basal segment of palp (coxobasis) with pinnate seta latero-basally, representing Exp; with 2 apical spiniform setae (1 smooth; 1 robust, bipinnate), and with subapical, smooth seta. Lateral segment with 2 apical and 1 subapical, pinnate setae.

Maxilla (Fig. 4e): 5-segmented. Endite of praecoxa prominent, with 1 bipinnate seta and 1 smooth seta. Proximal endite of coxa with pinnate seta; distal endite elongated, with 2 apical pinnate setae (more proximal seta ornamented with long setules; more distal seta with short spinules). Basis with apical claw-like expansion, ornamented with row of many spinules along concave margin; with 2 setae at base of claw; longer one as long as claw, smaller seta half as long, thin, inserted on caudal surface. Distal segment of exopod and endopod (Endp2)-segmented: Endp1 with 2 robust setae; Endp2 apically with robust seta as long as claw-like expansion on basis, and sub-apically with 2 slender, shorter setae, remnants of reduced apical segment of Endp.

Maxilliped (Figs. 4f and 3g): 4-segmented, composed of syncoxa, basis and 2-segmented Endp. Syncoxa ornamented on frontal surface with a group of spinules near outer margin; proximal endite with 2 apical, pinnate setae; longer one about 2 times as long as shorter one; distal endite with pinnate seta. Basis on frontal surface with a row of spinules, caudally with a group of spinules near outer margin, armed with 2 sub-equal, pinnate setae. Endp1 with strong seta. Endp2 armed with 3 setae, medial seta strong, apical and lateral setae slender, and smooth.

P1-P4 with two-segmented rami (Fig. 2a-c). Distal segment of exopod Exp2 and Endp2 with internal sclerotised ridges on inner margin in each swimming leg. Exp2 spine formula: 3.4.4.3. Complete armament of P1-P4 is provided in Tab. 2.

Pl (Fig. 2a): intercoxal sclerite naked, bearing short, round prominences. Coxa rectangular, armed with inner

Tab. 1. Morphometric differences between Fierscyclops tanaosriensis n. sp. and F. solaris n. sp.

\begin{tabular}{|c|c|c|c|c|}
\hline \multirow[t]{2}{*}{ Characters $(\mu \mathrm{m})$} & \multicolumn{2}{|c|}{ F. tanaosriensis $\mathrm{n} . \mathrm{sp}$. } & \multicolumn{2}{|c|}{ F. solaris $\mathrm{n} . \mathrm{sp}}$. \\
\hline & $\begin{array}{l}\text { Female } \\
(\mathrm{n}=10)\end{array}$ & $\begin{array}{l}\text { Male } \\
(\mathrm{n}=5)\end{array}$ & $\begin{array}{c}\text { Female } \\
(\mathrm{n}=8)\end{array}$ & $\begin{array}{l}\text { Male } \\
(\mathrm{n}=5)\end{array}$ \\
\hline Body length $^{\circ}$ & $805.1 \pm 16.6$ & $657.5 \pm 24.6$ & $733.0 \pm 17.7$ & $631.9 \pm 15.6$ \\
\hline Length of caudal rami ${ }^{\circ}$ & $\begin{array}{c}59.7 \pm 2.9 \\
(57-66)\end{array}$ & $\begin{array}{c}45.7 \pm 1.1 \\
(45-48)\end{array}$ & $\begin{array}{c}56.5 \pm 2.3 \\
(52-60)\end{array}$ & $\begin{array}{c}46.4 \pm 1.1 \\
(45-48)\end{array}$ \\
\hline Ratio of length/width of caudal $\mathrm{rami}^{\circ}$ & $\begin{array}{c}3.2 \pm 0.2 \\
(2.9-3.4)\end{array}$ & $\begin{array}{c}2.6 \pm 0.2 \\
(2.3-2.8)\end{array}$ & $\begin{array}{c}3.2 \pm 0.2 \\
(2.9-3.4)\end{array}$ & $\begin{array}{c}3.0 \pm 0.2 \\
(2.7-3.2)\end{array}$ \\
\hline Length of spine on $\mathrm{P} 5^{\circ}$ & $\begin{array}{c}25.5 \pm 1.1 \\
(24-27)\end{array}$ & $\begin{array}{c}16.8 \pm 1.8 \\
(15-19)\end{array}$ & $\begin{array}{c}19.6 \pm 0.7 \\
(18-20)\end{array}$ & $\begin{array}{c}18.8 \pm 0.4 \\
(18-19)\end{array}$ \\
\hline
\end{tabular}

Average lengths of setae

$22: 51: 167: 237: 49: 35$

$16: 46: 144: 207: 44: 26$

$20: 45: 163: 227: 46: 33$

$17: 40: 151: 222: 43: 23$

(II-VII)

${ }^{\circ}$ Data show mean \pm standard deviation; values in brackets represent range. 
Tab. 2. Complete armament of swimming legs of Fierscyclops tanaosriensis n. sp.

\begin{tabular}{|c|c|c|c|c|c|c|}
\hline \multirow[b]{2}{*}{ Swimming leg } & \multirow[b]{2}{*}{ Coxa } & \multirow[b]{2}{*}{ Basis } & \multicolumn{2}{|c|}{ Exopod } & \multicolumn{2}{|c|}{ Endopod } \\
\hline & & & 1 & 2 & 1 & 2 \\
\hline P1 & $0-1$ & 1-I & I-1 & III-2-3 & $0-1$ & $1-\mathrm{I}, 1-3$ \\
\hline P2 & $0-1$ & $1-0$ & $\mathrm{I}-1$ & III-I,1-4 & $0-1$ & $1-\mathrm{I}, 1-4$ \\
\hline P3 & $0-1$ & $1-0$ & I-1 & III-I,1-4 & $0-1$ & $1-\mathrm{I}, 1-4$ \\
\hline P4 & $0-1$ & $1-0$ & I-0 & II-I,1-4 & $0-1$ & 1-II-3 \\
\hline
\end{tabular}

Arabic numbers represent number of spines; roman numbers represent number of setae.

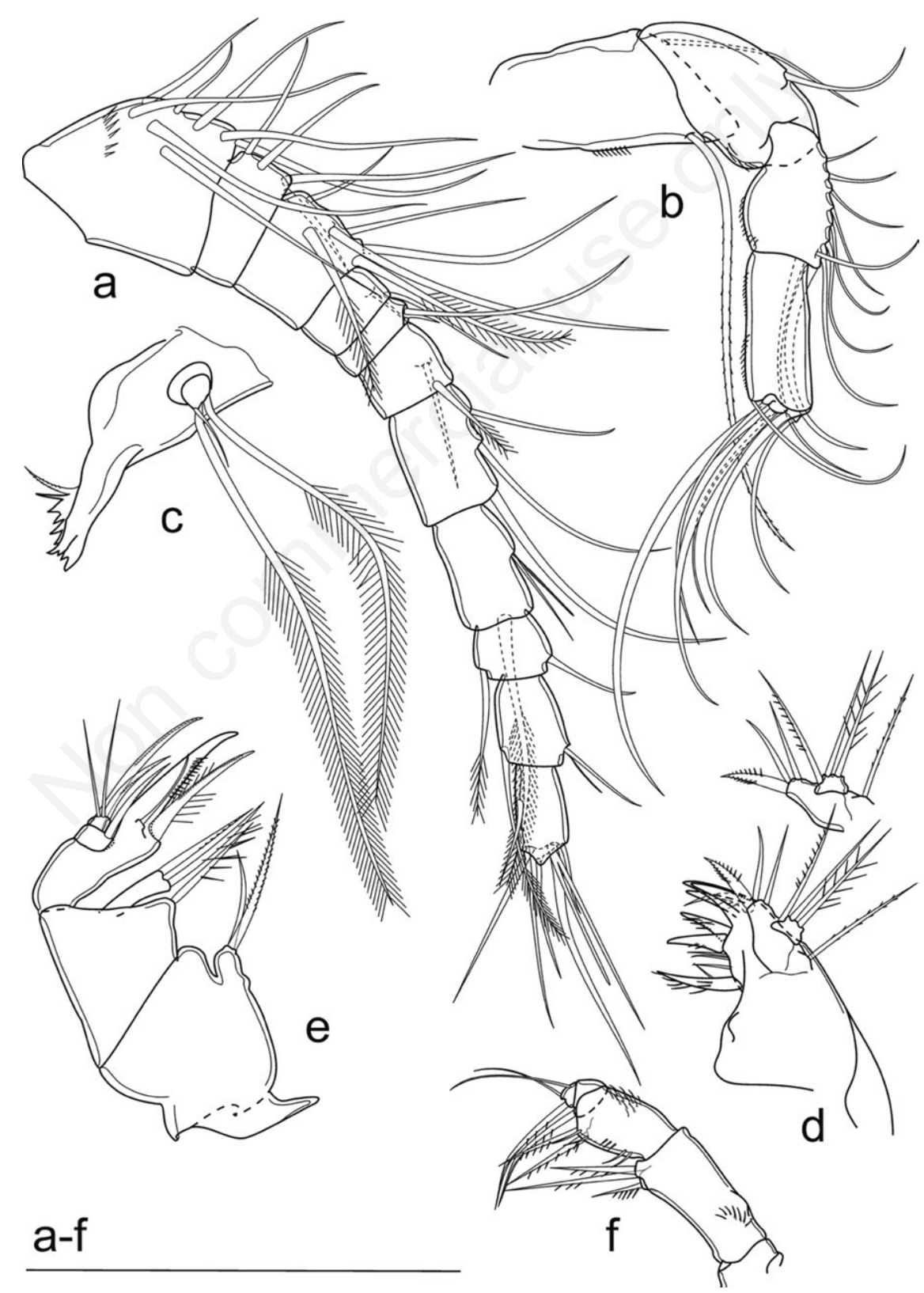

Fig. 4. Fierscyclops tanaosriensis n. sp., female (holotype): a) antennule, caudal view; b) antenna, frontal view; c) mandible, ventral view; d) maxillule, frontal view; e) maxilla, caudal view; f) maxilliped, frontal view. Scale bar: $0.1 \mathrm{~mm}$. 
seta on distal inner corner. Basis medially pilose, medial expansion rounded. Medial setiform spine extending well beyond tip of Endp2, outer seta of basis slender, setulose. Rows of spinules present at insertion of medial spine and near articulation of Endp. Proximal segment of exopod (Exp1) and Endp1 as long as wide. Exp2 and Endp2 ca. 1.5 times as long as wide.

P2 (Fig. 2b): intercoxal sclerite naked, without prominence. Coxa rectangular, armed with inner seta on distal inner corner. Basis medially pilose, medial expansion pointed (Fig. 5a). Outer seta of basis present, setulose. No spinules at insertion of Endp. Exp1 and Endp1 as long as wide. Exp2 and Endp2 about 1.5 times as long as wide; cuticular pore present near base of sub-apical spine of Exp2 and apical spine of Endp2.

P3: identical to P2 in shape and armament.

P4 (Fig. 2c): intercoxal sclerite, coxa, and basis similar to P2-P3 but outer seta on basis inserted on caudal surface. Endp2 with 2 apical spines, medial spine 1.5 times as long as the lateral one.

P5 (Figs. 2d, 2e and 5c): inserted on lateral corner of thoracic somite 5 , with proximal segment completely fused to somite; remnant of ancestral proximal segment represented by seta; seta inserted near insertion of free segment. Distal free segment, as wide as long, armed with slender, dorsal (outer) apical seta and very strong ventral (inner) apical spine; spine length $26 \mu \mathrm{m}$; seta about 1.3 times as long as spine.

P6 (Fig. 2e): small, forming simple cuticular plate inserted latero-dorsally on genital double-somite, and armed with 3 elements: seta and 2 minute spines, seta much longer than spines.

Male (allotype): body length, including caudal rami, $615 \mu \mathrm{m}$. Habitus smaller and slenderer than in female (Fig. 6a). Naupliar eye not discernible, rostrum as in female; prosome/urosome ratio about 1.5 (including caudal rami). Body length/width ratio ca. 4. Cephalothorax anteriorly oval, 1.2 times as long as wide, with greatest width at posterior end, representing $26 \%$ of body length. Posterior margins of all thoracic somites smooth. Genital somite globular (Fig. $6 a$ and 6 b), its length about $31 \%$ of length of rest of urosome, including caudal rami. Hyaline structures on dorso-lateral part well developed (Fig. 6a and $6 \mathrm{~b}$ ). Posterior border of genital somite and 3 subsequent somites with smooth hyaline frill. Anal somite and operculum as in female.

Caudal rami: relatively shorter than in female, about 2.8 times as long as wide. Armament and ornamentation similar to those in female. Length ratio of caudal setae to ramus length, from seta II to seta VII: 0.4:1.0:3.0:4.2:0.9:0.6. Length ratio of caudal setae from seta II to seta VII: 1:2.2:7.0:9.9:2.0:1.3 (details in Tab. 1).

Antennule (Fig. 6c): 16-segmented, digeniculate. Armature formula as follows: 8+3ae.4.1.2+ae.1.2.2.2.1+ae+ I.2.2.1+I.2+ae.2.2.11+ae, where Roman numbers indicate the number of spines, Arabic numbers the number of setae, and ae means aesthetasc. Segments 11-13 with pinnate seta each.

Antenna and mouth parts: similar to those in female.

P1-P4: similar to female, yet medial expansion of
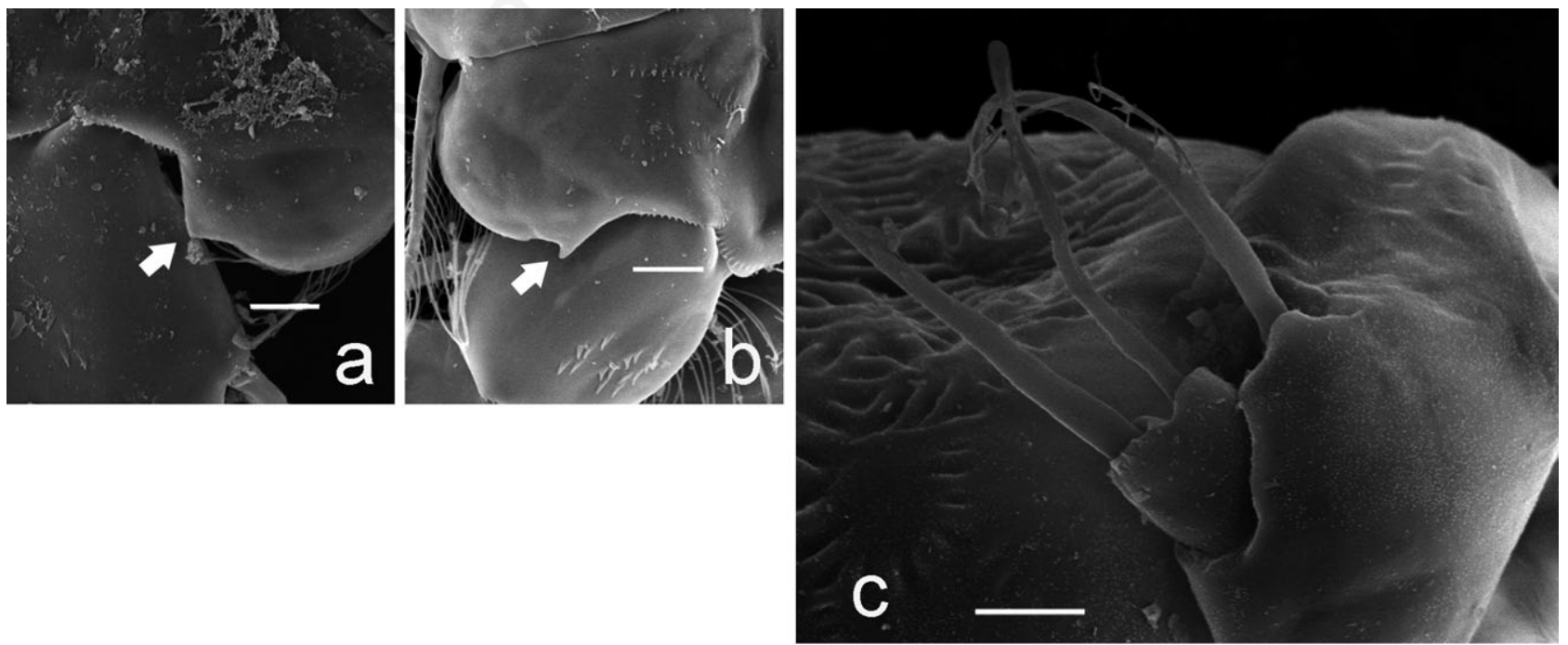

Fig. 5. Scanning electron micrographs. Fierscyclops tanaosriensis n. sp.: a) female. Fierscyclops solaris n. sp.: b,c) male. a,b) Medial expansion of swimming leg (arrows indicate hook on medial expansion of swimming leg), frontal view; c) P5, lateral view. Scale bars: $5 \mu \mathrm{m}(\mathrm{a}, \mathrm{b}) ; 2 \mu \mathrm{m}(\mathrm{c})$. 
basis of P2-P4 slightly curved inward (Fig. 6e), and medial spine on distal segment of $\mathrm{P} 4 \mathrm{ca} .1 .8$ times as long as lateral spine (Fig. 6d).

P5 (Fig. 6b) similar to that in female. Length of spine on free segment $19 \mu \mathrm{m}$, seta on free segment 1.1 times as long as spine, and lateral seta on thoracic somite 51.6 times as long as spine on free segment.

P6 (Fig. 6b): modified to rectangular cuticular plate with 3 elements, innermost spine, and middle and outermost setae. Innermost spine and middle seta sub-equal, outermost seta 1.5 times as long as innermost spine.

Variability: body length of female $752-828 \mu \mathrm{m}$ (mean: $805 \mu \mathrm{m} ; \mathrm{n}=10)$ and body length of male $615-677 \mu \mathrm{m}$ (mean: $657 \mu \mathrm{m} ; \mathrm{n}=5$ ). The tip of medial expansion on P2$\mathrm{P} 4$ basis in female is pointed, but that in male is curved inward (hook-like shaped). Maxilliped of one female ob-

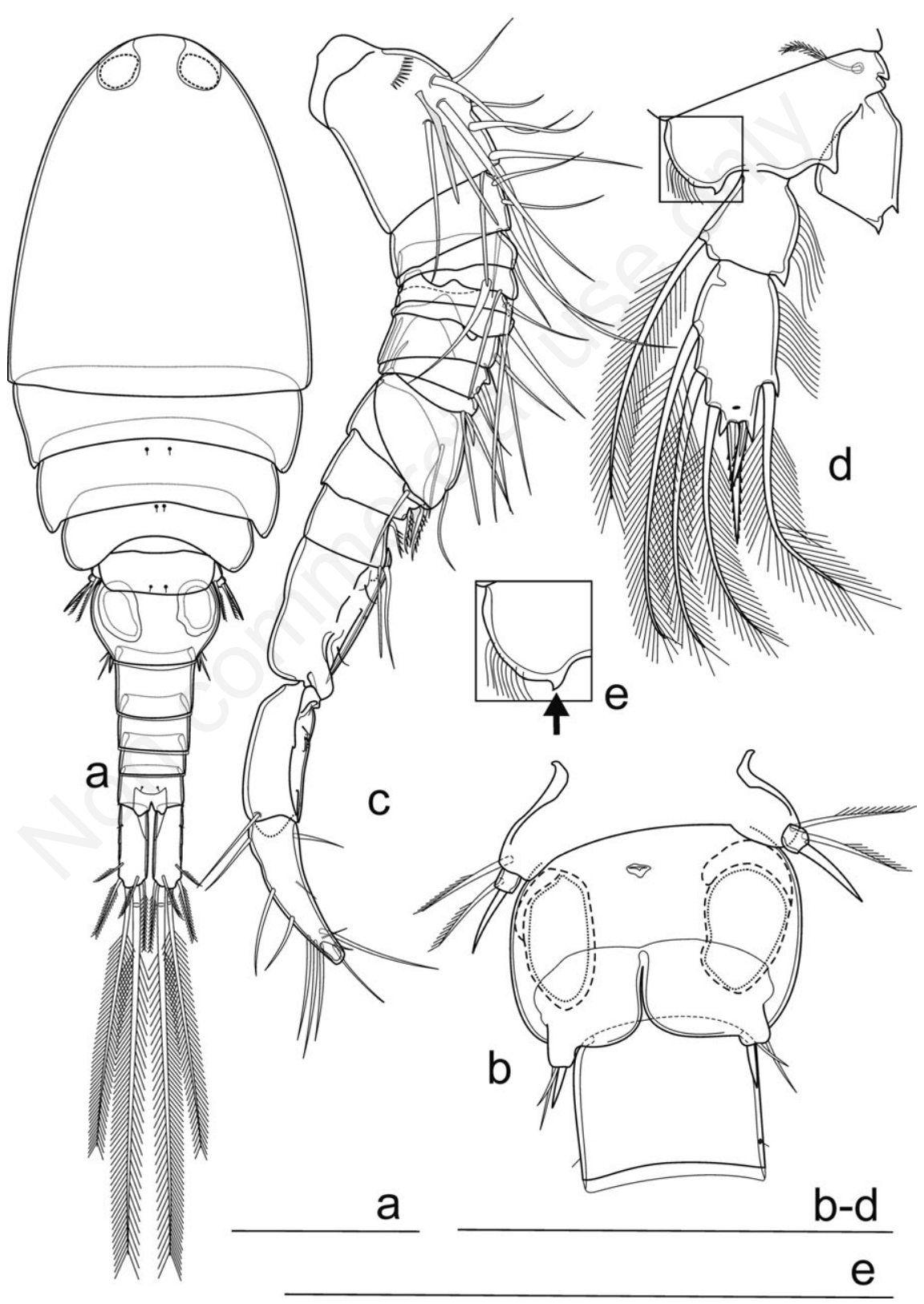

Fig. 6. Fierscyclops tanaosriensis n. sp., male (allotype): a) habitus, dorsal view; b) genital somite, ventral view; c) antennule, caudal view; d) protopodal segment and Endp of P4, frontal view; e) medial expansion of basis of P2-P4, hook is indicated by arrow. Scale bars: $0.1 \mathrm{~mm}$ 
served by SEM showed 2 arched rows of minute spinules on outer margin of syncoxa (Fig. 3g). No other significant variation has been observed in other characters, except for minor variation in the length of setae and spine on P5 and caudal rami (Tab. 1).

Fierscyclops solaris n. sp.

\section{Taxonomical account}

Type locality: small spring next to the entrance of a nameless cave in an isolated cone karst area. The karst is in an area of Wat Yang Kao temple (Kanchanaburi province, Thailand), $190 \mathrm{~km}$ northwest of the town of Kanchanaburi, and $260 \mathrm{~km}$ northwest of Bangkok. The coordinates are: $14^{\circ} 57^{\prime} 54.98^{\prime \prime} \mathrm{N}$; $98^{\circ} 37^{\prime} 51.12^{\prime \prime} \mathrm{E}$, elevation: $190 \mathrm{~m}$ asl. There is no running water in the cave. Samples were collected on 21 November 2010 by one of the authors (CB) just in front of the spring mouth, from among plant roots; water temperature was $24.8^{\circ} \mathrm{C}, \mathrm{pH} 6.7$, and conductivity was $508 \mu \mathrm{S} \mathrm{cm}$.

Material: holotype: adult female, completely dissected and mounted on a slide in glycerol and sealed with nail polish; deposited in the Natural History Museum (London), registration No. NHM 2012.1501. Allotype: adult male, completely dissected and mounted on a slide in glycerol and sealed with nail polish; collected at the same time and location as the holotype; deposited in the Natural History Museum (London), registration No. NHM 2012.1506.

Paratypes (all specimens collected at the same time and in the same place as the holotype): 2 adults $q+9$ and 2 adults ${ }^{A}{ }^{-1}$ (stored in 70\% alcohol); deposited in the Natural History Museum (London), registration Nos. NHM

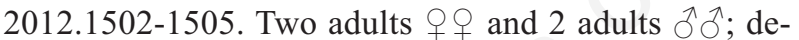
posited in the Science Museum of Khon Kaen University, Thailand; registration Nos. KKU-COP-2012-002.

Additional specimens (all specimens collected at the same time and in the same place as the holotype): one adult $\uparrow$ and one adult $\sigma^{\lambda}$ used for taking photographs by SEM.

Etymology: the specific name solaris is a Latin word (adjective), and means solar. It is an allusion to the characteristic body integumental ornamentation.

\section{Description}

Female (holotype): total body length, measured from tip of rostrum to posterior margin of caudal rami, $748 \mu \mathrm{m}$. Prosome about 1.4 times as long as urosome (including caudal rami) (Fig. 7a). Naupliar eye not discernible; rostrum similar to that in F. tanaosriensis n. sp. Body length/width ratio about 3.5. Cephalothorax anteriorly oval, as long as wide, with greatest width at the posterior end of the cephalothorax, representing $28 \%$ of body length. Posterior margins of cephalothorax and thoracic somites smooth; thoracic somite 2 with numerous small integumental invaginations along posterior margin (Figs. $7 \mathrm{a}, 7 \mathrm{~b}$ and $3 \mathrm{~b}$ ). Body integument with low oval cuticular areas surrounded by radial ridges; structure resembling sun (Figs. 7a and 3a); not strongly chitinised and no cuticular windows visible. Last 3 thoracic somites with 2 dorsal sensilla each. Thoracic somite 5 with slender lateral seta on each side, representing vestigial remnant of ancestral proximal segment of P5.

Genital double-somite similar to $F$. tanaosriensis $\mathrm{n}$. sp., 0.9 times as wide as long, tapering posteriorly.

Caudal rami similar to $F$. tanaosriensis n. sp., yet spinule ornamentation more prominent (Fig. 3c). Length ratio of caudal setae to ramus length, from seta II to seta VII: 0.4:0.7:2.8:4.1:0.8:0.7 and length ratio of caudal setae from seta II to seta VII: 1.0:1.9:7.6:11.1:2.1:1.8 (details in Tab. 1).

Antennule, antenna, mandible, maxillule, and maxilla: similar to those in F. tanaosriensis $\mathrm{n}$. sp.

Maxilliped (Figs. 7c and 3h): similar to that in $F$. tanaosriensis $\mathrm{n}$. sp., except for syncoxa having a row of large spinules on distal outer margin.

Labrum (Fig. 7d): trapezoidal, with 2 rows of hair. Cutting edge medially with 12 teeth between 2 rounded, lateral teeth.

Characters of P1-P4 (Fig. 8a-c, 8e): similar to those in female of $F$. tanaosriensis $\mathrm{n}$. sp., yet medial expansion on basis hook-like in P2-P4 (Fig. 5b), and medial spine on P4 Endp2 about 1.7 times as long as lateral spine.

$P 5$ : similar to $F$. tanaosriensis $\mathrm{n}$. sp. Free segment bearing one robust spine about $20 \mu \mathrm{m}$, and one seta 1.3 times as long as spine. Lateral seta on thoracic somite 5 about 1.9 times as long as spine on free segment.

P6: forming simple cuticular plate, inserted latero-dorsally on genital double-somite, and armed with 1 seta and 2 minute spines, seta much longer than spines.

Male (allotype): body length, including caudal rami, $645 \mu \mathrm{m}$. Habitus smaller and slenderer than in female (Fig. 7e). Naupliar eye not discernible, rostrum as in female; prosome/urosome ratio about 1.3 (including caudal rami). Body length/width ratio ca. 4.0. Cephalothorax and thoracic somites similar to those in female. Cephalothorax anteriorly oval, 1.2 times as long as wide, with greatest width at posterior end, representing $25 \%$ of body length. Genital somite globular (Fig. 7e), length about $32 \%$ of length of rest of urosome, including caudal rami. Hyaline structures on dorso-lateral part well developed (Fig. 7e). Posterior border of genital somite with smooth hyaline frill. Anal somite and operculum as in female.

Caudal rami relatively shorter than in female, about 2.9 times as long as wide. Armament and ornamentation similar to those in female. Length ratio of caudal setae to ramus length, from seta II to seta VII: 0.4:0.8:3.3:4.6:0.9: 0.5 ; and length ratio of caudal seta from seta II to seta VII: 1.0:2.4:9.4:13.1:2.5:1.4 (details in Tab. 1). 
Antennule similar to that in male of $F$. tanaosriensis n. sp.

Antenna, mandible, maxillule, maxilla, maxilliped, and P1-P4 as in female. Medial apical spine on P4 Endp2 about 1.7 times as long as lateral one (Fig. 8d).

P5 as in female (Figs. 1b, 2d, 2e and 5c). Spine $19 \mu \mathrm{m}$ long, seta on free segment as long as spine, and lateral seta on thoracic somite 5 about 1.5 times as long as spine.

P6 (Fig. 7f): with rectangular cuticular plate bearing medial spine, and middle and lateral setae; length of 3 elements sub-equal.

Variability: body length of female 697-750 $\mu \mathrm{m}$ (mean: $733 \mu \mathrm{m} ; \mathrm{n}=8$ ), and body length of male $611-648 \mu \mathrm{m}$ (mean: $632 \mu \mathrm{m} ; \mathrm{n}=5)$. The male observed by SEM lacks small in-

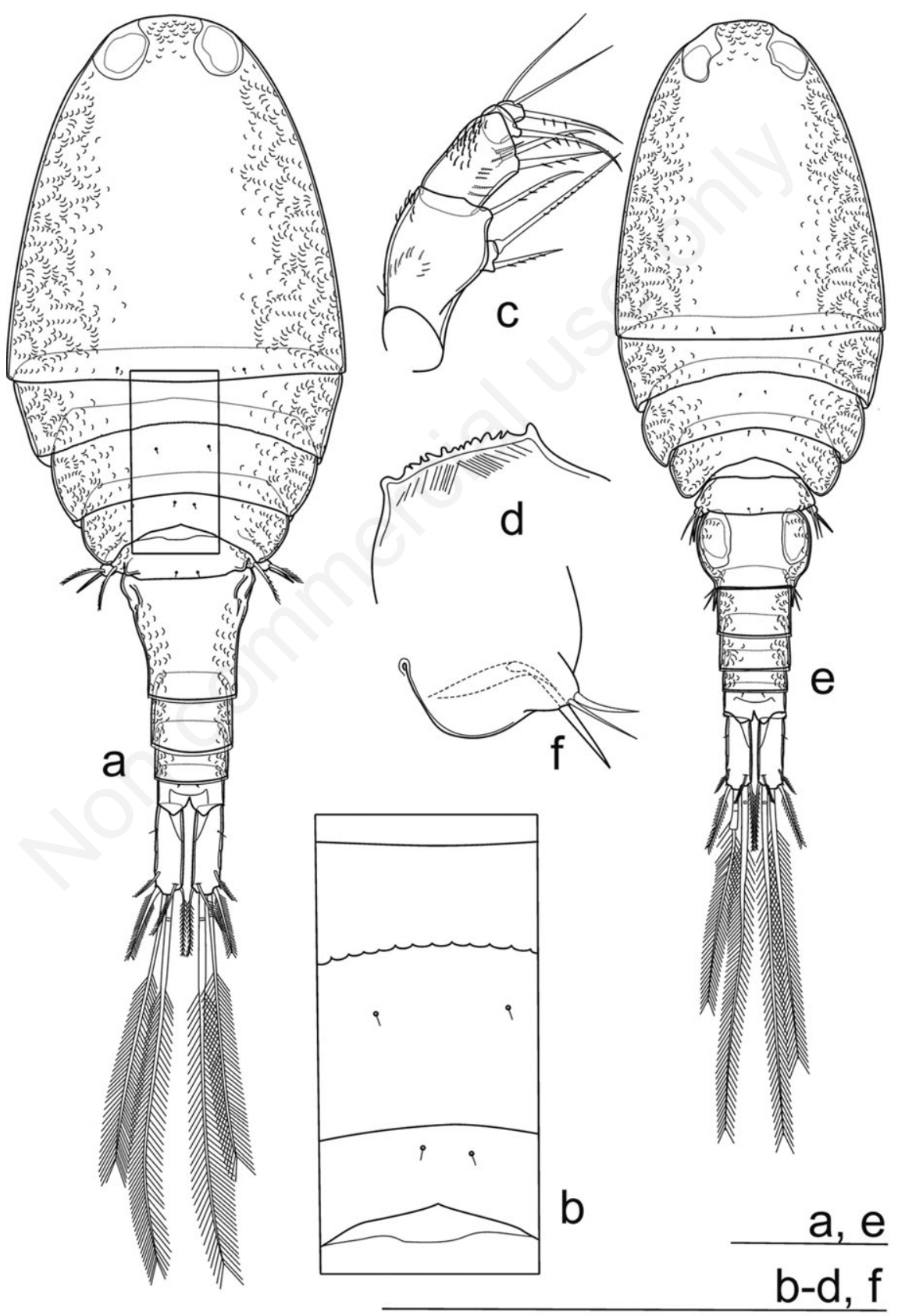

Fig. 7. Fierscyclops solaris n. sp. female (holotype): a) habitus, dorsal view; b) posterior margin of cephalosomatic segments; c) maxilliped, laterocaudal view; d) labrum, frontal view. Male (allotype): e) habitus, dorsal view; f) P6, ventrolateral view. Scale bars: $0.1 \mathrm{~mm}$. 
vaginations along posterior margin of thoracic somite 2 (Fig. 3d). No other significant variation has been observed in other features, except for minor differences in length of setae and spine of P5 and caudal rami (Tab. 1).

\section{DISCUSSION}

Research on the cave-dwelling Copepoda in Thailand has started just recently, therefore the number of sampling points in karstic environments is still low (Brancelj et al., 2010; Watiroyram et al., 2012). Also, our material was not preserved in the correct medium to confirm the existence of cryptic species by molecular markers. However, the specimens of the genus Fierscyclops collected from two localities in Thailand differ in several morphological characters, which support their accommodation into two new species: i) ornamentation of the body integument, ii) ornamentation of the syncoxa of the maxilliped, iii) shape

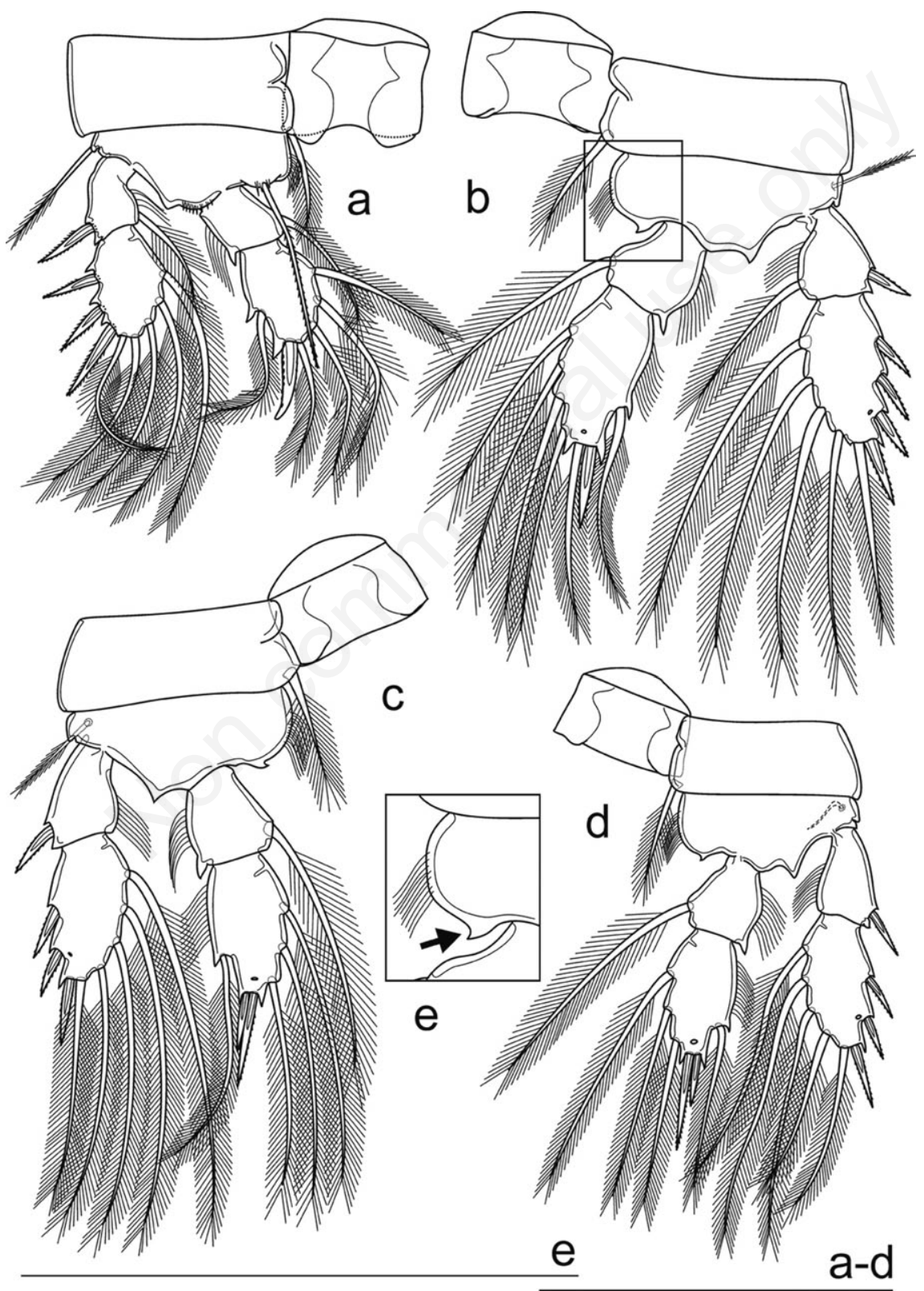

Fig. 8. Fierscyclops solaris n. sp. female (holotype): a) P1, frontal view; b) P3, frontal view; c) P4, frontal view. Male (allotype): d) P4, frontal view. Female (holotype): e) medial expansion of P3, hook is indicated by arrow. Scale bars: $0.1 \mathrm{~mm}$. 
of the posterior margin of the thoracic somite 2, and iv) medial hook-like expansion on the basis of P2-P4 in females. Except for the conspicuous differences in the integumetal ornamentation of the body segments (smooth in F. tanaosriensis n. sp., yet richly ornamented in F. solaris $\mathrm{n}$. sp.), the other differences are slight. A low degree of the differentiation in the morphological characters indicates relatively recent separation of the species, which might be a consequence of fragmentation of the karstic environment in the near past (Watiroyram et al., 2012). Ornamentation of the body integument in F. solaris $\mathrm{n}$. sp. is not an artefact (due to fixation), but it is a well formed and constant pattern in both sexes. As to the differences in the spinule ornamentation of the syncoxa of the maxilliped, the SEM observations showed that distal spinules on the outer margin of the segment are present in both species, yet the spinules are larger in F. solaris n. sp. (Fig. $3 \mathrm{~g}$ and $3 \mathrm{~h}$ ). These slight but constant differences support the existence of two species. Hook-like shaped medial expansions of $\mathrm{P} 2-\mathrm{P} 4$ are present in both sexes of $F$. solaris n. sp, while they are absent in the female but present in the male of $F$. tanaosriensis $\mathrm{n}$. sp. The character state shared by the males of both species might indicate a common ancestor.

Based on a re-definition provided by Karanovic et al. (2011), we accommodate both new species in the genus Fierscyclops that has previously been recorded from the Murchison region in Western Australia only. The new species from Thailand and F. fiersi share a combination of the characters: i) 2-segmented Endp and Exp of P1-P4, ii) two apical spines on Endp2 of P4, iii) short anal operculum, iv) protopod of P5 completely fused to thoracic somite 5 (but protopodal seta present), v) free segment of P5 inserts on lateral corner of thoracic somite 5, vi) large inner apical spine on free segment of P5, vii) large insertion distance between the apical spine and outer apical seta on free segment of P5, viii) presence of large lateral sensillum on caudal ramus, ix) spine and seta formula of Exp2 of swimming legs are 3.4.4.3 and 5.5.5.5, respectively, and x) 11-segmented antennule. Within the subfamily Cyclopinae, the combination of the characters i, iii, iv-viii, and $\mathrm{x}$ are also shared by Meridiecyclops and Pilbaracyclops, so far recorded from Australia only (Karanovic et al., 2011). The new taxa from Thailand and F. fiersi differ from the two Meridiecyclops species in having two apical spines on Endp2 of P4 (vs one spine in Meridiecyclops) and lacking the following characters of Meridiecyclops: axe-shaped plate or crescent-shaped extension on medial margin of basis of P4 in female, sclerotised crest or crescent flap on proximal half of genital double-somite in female, and the modification of the basis of the maxilla in male (Karanovic, 2004a). The Thai species can be distinguished from Pilbaracyclops as well, because the latter genus has a spine formula 3.3.3.3 for the Exp2 of P1-P4, apical seta and apical spine on Endp2 of P4, relatively shorter caudal rami, 6 setae on the second endopodal segment of antenna, setal formula of the maxilliped 2.2.1.2. (vs 3.1.2.3 in Fierscyclops), and lacks the exopodal seta on the antenna (Karanovic, 2006). Teratocyclops, Menzeliella, Pescecyclops, and Apocyclops, though sharing some characters of Fierscyclops (one-segmented P5, apical spine and apical seta on free segment of P5, P1-P4 with 2-segmented rami, and short anal operculum), can be distinguished from the new species by the same set of characters of P5 that also separates F. fiersi from the four above mentioned genera (Karanovic, 2004a, 2006; Karanovic et al., 2011).

On the other hand, there are a few characters in the new taxa and F. fiersi, which fit within the morphological variability of the genus Metacyclops Kiefer, 1927, though this genus is supposed to be polyphyletic and should be divided into several genera, as was suggested by Karanovic (2004a, 2004b) and Defaye and Por (2010). The new species and F. fiersi are similar to M. chelazzi Dumont, 1981, M. micropus Kiefer, 1932, M. mutatus Herbst, 1988, and M. leptopus totaensis Reid, Arevaro \& Fukushima, 1990 in having a relatively large apical spine and short seta on the free segment of P5, but they differ from the above mentioned taxa in the large insertion distance between the apical spine and seta of P5. While M. cushae has a large insertion distance between the spine and seta on the free segment of P5, but the inner apical spine is small. Nevertheless, the posterior portion of the seminal receptacle is well developed in Metacyclops, differing from Fierscyclops. Also, without remarkably enlarging the generic diagnosis of the genus, the ten-setae state on the second endopodal segment of the antenna precludes assigning the new species to the genus Metacyclops.

Fierscyclops, Pilbaracyclops, and Hesperocyclops have a large insertion distance between the apical spine and seta on the free segment of P5 and it supposedly is an indication of their common Apocyclops-like ancestor (Karanovic, 2004a; Karanovic et al., 2011). The presence of ten setae on the inner margin of the second endopodal segment of the antenna also supports the close phylogenetic relationship between the new species and Apocyclops, since this character state has so far been known in the latter genus only. Apocyclops is an epigean group, widely distributed both in fresh and brackish water. Most Apocyclops species have been encountered in the tropical and sub-tropical regions: Arouba, Australia, Borneo, Brazil, Central America, China, Colombia, Guadalupe, India, Ivory Coast, Japan, Kazakstan, Mexico (Yucatan), Nicaragua, Peru, Thailand, USA, Uzbekistan, and Venezuela (Dussart and Defaye, 2006). It is likely that the smaller body size (including reduced ratio of length/width of the genital double-somite) and seta losses on the body appendages are apomorphic character states in Fierscy- 
clops when compared to the respective states in the closely related genus, Apocyclops. Morphological shifts towards reductions can be connected to habitat changes from surface to subterranean waters $(F$. fiersi is only known from bore-wells-porous aquifer). It is important to mention that similar reductions appear in many other cyclopid groups, and if the reductional characters are adaptations to a subterranean environment it is problematic to infer phylogenetic relatedness from the similarity (Huys and Boxshall, 1991; Galassi, 2001; Galassi et al., 2009).

The new Fierscyclops species from Thailand can be distinguished from the Australian generic type-species by: i) the presence of large lateral sensilla on the caudal rami in the male, ii) more elongate genital double-somite, iii) coxobasis and second endopodal segment of the antenna with two and ten setae, respectively, iv) stronger apical spine on the free segment of $\mathrm{P} 5, \mathrm{v}$ ) presence of internal sclerotised ridges on Exp2 and Endp2 of P1-P4, vi) relatively shorter caudal rami, and vii) shorter dorsal seta on the caudal ramus. The new species have been collected in two isolated cone karst areas, ca. $40 \mathrm{~km}$ apart. The sampling locations are in an intensively karstified area, belonging to the Kwai Noi river sub-basin, but there are no connections between the locations through surface water bodies. The new species have never been encountered before; although, samplings were conducted in various surface water bodies in the southern part of the sub-basin and in other regions of Thailand, as well as in Cambodia and Laos (Sanoamuang, personal communication). Furthermore, neither the close relatives of the species nor the closely related genera were ever found during the sampling campaign in 20 caves in northern Thailand. It is plausible, that horizontal migrations of stygobionts across non-karstic environments are very limited.

\section{CONCLUSIONS}

The geographic distribution of the subterranean species in some genera, such as Speocyclops Kiefer, 1937 or Hesperocyclops Herbst, 1984, is limited to certain regions. This probably indicates low dispersal ability or strong ecological barriers preventing those subterranean copepods from invading larger areas. On the other hand, genera, such as Haplocyclops Kiefer, 1952 [South America (Brazil), continental Africa, Madagascar, Iran, and India] and Rybocyclops Dussart, 1982 (Madagascar and India) exhibit wide, Gondwana distribution (Karanovic and Ranga Reddy, 2005; Ranga Reddy and Defaye, 2008). The block containing northern South America, Africa, Madagascar, and India separated from the rest of the Gondwana supercontinent in the Jurassic/Early Cretaceous about 150-140 million years ago (MYA); Madagascar-India separated from Africa ca. 121 MYA (Sanmartín and Ronquist, 2004). The geographical distribution of the representatives of the genus Fierscyclops might suggest a very old origin of Fierscyclops as well. Thailand was formed by two continental blocks, the Indochina and Sibumasu terranes, which separated from Gondwanaland in the Devonian and late Early Permian, respectively (Metcalfe, 1998). Yet, a lot more additional information on the morphology, phylogenetic relationships and geographic distribution are needed to get a clearer picture of the origin of Fierscyclops in Thailand and the freshwater cyclopoid copepods in SE Asia in general.

\section{ACKNOWLEDGMENTS}

This work was supported by Thailand's Commission on Higher Education under the programme Strategic Scholarships for Frontier Research Network. The authors wish to thank Dr. Maria K. Hołyńska and three anonymous reviewers whose comments and recommendations made significant contributions to the improvement of previous version of the manuscript, Dr. Jolyon Dodgson for his help with the English corrections, and Mr. Boonsong Kongsook for taking scanning electron microscopy photographs.

\section{REFERENCES}

Alekseev VA, Sanoamuang L, 2006. Biodiversity of cyclopoid copepods in Thailand with a description of Afrocyclops henrii sp. n. Arthropoda Sel. 15:277-290.

Boonsom J, 1984. The freshwater zooplankton of Thailand (Rotifera and Crustacea). Hydrobiologia 113:223-229.

Brancelj A, 2000. Morariopsis dumonti n. sp. (Crustacea:Copepoda:Harpacticoida) - a new species from an unsaturated karstic zone in Slovenia. Hydrobiologia 436:73-80.

Brancelj A, 2005. Hadodiaptomus dumonti n. gen., n. sp., a new freshwater stygobitic calanoid (Crustacea: Copepoda: Calanoida) from Vietnam (South Asia) and a new member of the subfamily Speodiaptominae Borutzky, 1962. Hydrobiologia 534:57-70.

Brancelj A, 2009. Fauna of an unsaturated karstic zone in central Slovenia: two new species of Harpacticoida (Crustacea: Copepoda), Elaphoidella millennii n. sp. and E. tarmani n. sp., their ecology and morphological adaptations. Hydrobiologia 621:85-104.

Brancelj A, Watiroyram S, Sanoamuang L, 2010. The first record of cave-dwelling Copepoda from Thailand and description of a new species: Elaphoidella namnaoensis n. sp. (Copepoda, Harpacticoida). Crustaceana 83:779-793.

Bricker, KS, Wongrat L, Gannon JE, 1978. Composition and distribution of crustacean plankton in twelve inland water bodies of Thailand. KU Fish. Res. Bull. 10:1-14.

Chaicharoen R, Sanoamuang L, Hołyńska M, 2011. A review of the genus Thermocyclops (Crustacea: Copepoda: Cyclopoida) in Cambodia. Zool. Stud. 50:780-803.

Defaye D, Por FD, 2010. Metacyclops (Copepoda, Cyclopidae) from Ayyalon Cave, Israel. Crustaceana 83:399-423.

Deharveng L, Bedos A, 2000. The cave fauna of Southeast Asia. Origin, evolution and ecology, p. 603-632. In: H. Wilkens, D.C. Culver and W.F. Humphreys (eds.), Ecosystems of the world. Subterranean ecosystems. Elsevier Academic Press. 
De Laurentiis P, Pesce GL, Humphreys WF, 2001. Copepods from ground waters of Western Australia, VI. Cyclopidae (Crustacea: Copepoda) from the Yilgarn region and the Swan coastal plain. Rec. Aust. Mus. 64:115-131.

Dussart BH, Defaye D, 2006. World directory of crustacean copepods of inland waters. II. Cyclopiformes. Backhuys Publ., Leiden: 354 pp.

Galassi DMP, 2001. Groundwater copepods: diversity patterns over ecological and evolutionary scales. Hydrobiologia 453/454:227-253.

Galassi DMP, Huys R, Reid JW, 2009. Diversity, ecology and evolution of groundwater copepods. Freshwater Biol. 54:691-708.

Gibert J, Deharveng L, 2002. Subterranean ecosystems: A truncated functional biodiversity. BioScience 52:473-481.

Huys R, Boxshall GA, 1991. Copepod evolution. The Ray Society Publ., London: 468 pp.

Karanovic T, 2004a. Subterranean copepoda from Arid Western Australia. Brill ed., Leiden: 366 pp.

Karanovic T, 2004b. The genus Metacyclops Kiefer in Australia (Crustacea: Copepoda: Cyclopoida), with description of two new species. Rec. Aust. Mus. 22:193-212.

Karanovic T, 2006. Subterranean copepods (Crustacea, Copepoda) from the Pilbara region in Western Australia. Rec. Aust. Mus. 70:1-236.

Karanovic T, Eberhard SM, Murdoch A, 2011. A cladistic analysis and taxonomic revision of Australian Metacyclops and Goniocyclops, with description of four new species and three new genera (Copepoda, Cyclopoida). Crustaceana 84:1-67.

Karanovic T, Ranga Reddy Y, 2005. First Haplocyclops Kiefer
(Crustacea, Copepoda) from Indian subterranean waters: the most reduced free-living cyclopoid. Ann. Limnol.-Int. J. Lim. 41:83-92.

Lim RP, Fernando CH, 1985. A review of Malaysian freshwater Copepoda with notes on new records and little known species. Hydrobiologia 128:71-89.

Metcalfe I, 1998. Palaeozoic and Mesozoic geological evolution of the SE Asia region: multidisciplinary constraints and implications for biogeography, p. 25-41. In: R. Hall and J.D. Holloway (eds.), Biogeography and geological evolution of SE Asia. Backhuys Publ.

Ranga Reddy Y, Defaye D, 2008. Discovery of the genus Rybocyclops Dussart, 1982 (Crustacea, Copepoda, Cyclopoida) in subterranean ground waters of southeastern India, with the description of a new species and its biogeographic significance. Zootaxa 1810:40-50.

Reid JW, 1991. The genus Metacyclops (Copepoda: Cyclopoida) present in North America: M. cushae, new species, from Louisiana. J. Crustacean Biol. 11:639-646.

Sanmartín I, Ronquist F, 2004. Southern hemisphere biogeography inferred by event-based models: plant versus animal patterns. Syst. Biol. 53:216-243.

Sanoamuang L, 1999. Species composition and distribution of freshwater Calanoida and Cyclopoida (Copepoda) of Northeast Thailand, p. 217-230. In: F.R. Schram and J.C. von Vaupel Klein (eds.), Proc. $4^{\text {th }}$ Int. Crustacean Congr. 1998. 1. Crustaceans and the biodiversity crisis. Brill ed., Leiden.

Watiroyram S, Brancelj A, Sanoamuang L, 2012. A new Bryocyclops Kiefer (Crustacea: Copepoda: Cyclopoida) from karstic caves in Thailand. Raffles B. Zool. 60:11-21. 